\section{Sustainable Approach of Recycling Palm OIL Mill EFFLUENT (POME) USING INTEGRATED BIOFILM/MEMBRANE FILTRATION SYSTEM FOR INTERNAL Plant Usage}

Article history

Received

13 May 2017

Received in revised form

13 February 2018

Accepted

1 March 2018

Published online

3 June 2018

*Corresponding author yh_teow@ukm.edu.my

aFaculty of Engineering and Built Environment, Univ
Kebangsaan Malaysia, 43600 UKM Bangi, Selangor, Malaysia bCentre for Sustainable Process Technology (CESPRO), Faculty of Engineering and Built Environment, Universiti Kebangsaan Malaysia, 43600 UKM Bangi, Selangor, Malaysia

Graphical abstract

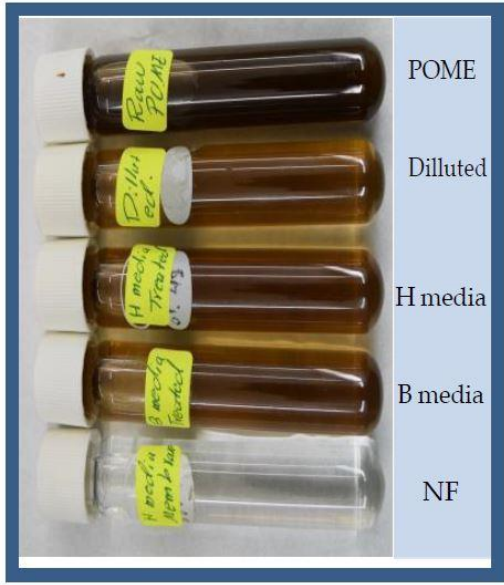

\section{Abstract}

Palm oil mill effluent (POME) is a massive problem to the environment, primarily waterway as it contains a considerable range of pollutants. Therefore, while enjoying the high revenue from palm oil industry, the palm oil industry responsibility towards the POME treatment must be taken into consideration. Along with the development of sustainable engineering concept, many researchers have focused on inventing a system that does not compromise the natural environment or the ability of future generations to meet their own needs. This study aimed to investigate the feasibility of using integrated biofilm treatment/membrane filtration process in producing recyclable and reusable water by manipulating the biofilm carrier type and the biofilm treatment HRT. The combined system of biofilm and membrane had delivered $98.6,99.98,97.5,100$, and $99.87 \%$ of COD, Turbidity, MLSS, TSS, and ammoniacal nitrogen removal, respectively. The produced permeate from aerobic POME remediation by biofilm/ membrane filtration system meets the III and IV class of the National Water Quality standards of Malaysia for water supply (Extensive treatment is required), and fishery (livestock drinking) purpose.

keywords: Palm oil mill effluent, integrated system, biofilm treatment, membrane filtration, water treatment

(c) 2018 Penerbit UTM Press. All rights reserved

\subsection{INTRODUCTION}

A massive quantity of water is required for the palm oil extraction process, especially fresh fruit bunch (FFB) sterilisation and extracted oil clarification [1]. The process requires around 5-7.5 tonnes of water to produce one tonne of crude palm oil (CPO), and this massive quantity of water ends up as palm oil mill effluent (POME) [2]. POME comprises $0.6-0.7 \%$ of oil, $95-96 \%$ of water and suspended solids in the range of $2-4 \%$ [3]. This vast quantity of polluted wastewater will result in severe waterways pollution and bring negative impact to the aquatic habitats due to oxygen depletion and the increase of freshwater acidification [4]. Currently, Palm oil production increases due to the vast demand for oleochemicals. Thus, POME discharge is increasing [5].

There are several methods commonly used in treating $\mathrm{POME}$, for instance, biological treatment such as facultative or anaerobic ponding system [6]. However, long hydraulic retention time (HRT) (45-60 days), production of greenhouse gases (hydrogen 
sulphide, carbon dioxide, methane), and significant area requirement are the constraints of the biological treatment [7]. Evaporation is another method that used to treat POME [8]. Evaporation had contributed to the expensive operating cost due to the high energy consumption, which is the main drawback of this method.

Biofilm technology used for the first time in year 1990s, for treating wastewater in Norway [9]. Numerous microbes use nutrients (organic and inorganic matters) to build a biofilm colony. First, the microbes attach to a suitable surface; then it starts developing the colony. Biofilm treatment has many advantages compared to the conventional POME treatment methods. For instance, high activity biomass, resilience to the environmental changes, reduced hydraulic retention time, low space required, flexibility in the treatment operation, and enhanced ability to degrade recalcitrant compounds [10].

In 2010, the World Health Organization (WHO) had shown that 780 million people have no way to get the suitable water for drinking. That issue had raised considerable concern to provide well treatment [11]. For producing high-quality water, the system involved the membrane treatment. This research had integrated Membrane with Biofilm treatment to produce a high-quality treatment. The system included Biofilm as pretreatment to avoid the foul matter [12].

The primary objective of this study could achieve by manipulating the type of biofilm carrier and the biofilm treatment retention time, and to investigate the feasibility of using integrated biofilm treatment/ membrane filtration process in producing recyclable and reusable water. Bagheripour and Moghadassi (2015) had catalysed their membrane treatment to provide better treatment, but in this research, it had focused on the integration process [13].

\subsection{METHODOLOGY}

\subsection{Materials}

The used POME sample collected from aerobic pond in Sime Darby east mill, Carey Island, Malaysia (see Table 1).

Table 1 Aerobic POME properties

\begin{tabular}{lll}
\hline Parameters & Unit & Value \\
\hline COD & $\mathrm{mg} \backslash \mathrm{I}$ & 6630 \\
Turbidity & $\mathrm{NTU}$ & 3740 \\
$\mathrm{Ph}$ & $\mathrm{mg} \backslash \mathrm{I}$ & 5.693 \\
$\mathrm{MLSS}$ & $\mathrm{gm}$ & 0.012 \\
$\mathrm{NH} 3-\mathrm{N}$ & $\mathrm{mg} \backslash \mathrm{I}$ & 970 \\
Temperature & ${ }^{\circ} \mathrm{C}$ & 27.8 \\
\hline
\end{tabular}

POME sample was kept under $6{ }^{\circ} \mathrm{C}$ in the cold room immediately after the sampling to avoid biodegradation of POME by micro-organisms [14]. Black media and hexafilter media bought from EnviroSource Company, Malaysia. These growth media used as carriers for biofilm bacteria attachment. The membrane technology performed a Nano Filtration (NF). The filtration process occurred by NF270 membrane type in the cross-flow membrane. NF270 is the product of the DOW, USA. Table 2 presents biofilm carriers (Black and Hexafilter) with their specifications.

Table 2 Characteristics of Biofilm carriers

\begin{tabular}{lll}
\hline Characteristics & Black Media & Hexafilter Media \\
\hline Appearance & & \\
& & \\
Material & Polypropylene & Polyethylene \\
Density $\left(\mathrm{kg} / \mathrm{m}^{3}\right)$ & 0.888 & 1.034 \\
Specific surface & 450 & 320 \\
area $\left(\mathrm{m}^{2} / \mathrm{m}^{3}\right)$ & & 1460 \\
Surface area & 1400 & 1.034 \\
(mm²) & 0.654 & 12 \\
Mass $(\mathrm{g})$ & 10 & \\
Height $(\mathrm{mm})$ & &
\end{tabular}

The used membrane sort for POME filtration was nanofiltration (NF). Also, NF270 was the utilised NF type. This NF270 membrane purchased from the DOW Chemical Company, USA.

\subsection{Acclimatization of Biofilm}

POME employed as a nutrient source for the bacteria colonisation on the growth media. Prior acclimatisation process, POME collected from an aerobic pond at Sime Darby east mill, Carey Island, Malaysia. Centrifugation process handled POME for 10 minutes at speed $4000 \mathrm{rpm}$. One litre of concentrated POME was collected and mixed into a glass tank filled with one litre of aerobic POME. 126 pieces of the hexafilter carrier and 328 pieces of the black media were added to the glass tank separately. The mixture was left untreated for biofilm growth on the carriers to metabolise the organic matters in POME. Figure 1 presents the map of the operation.

\subsection{Biofilm Treatment}

The biological treatment used the developed biofilm to biodegrade and mineralise POME After the acclimatisation stage. The biofilm treatment would last for three days. During these three days, COD, Turbidity, pH, MLSS, NH3-N, Temperature, Dissolved Oxygen, and TSS presented the biofilm treatment progress for every 24 hours. 


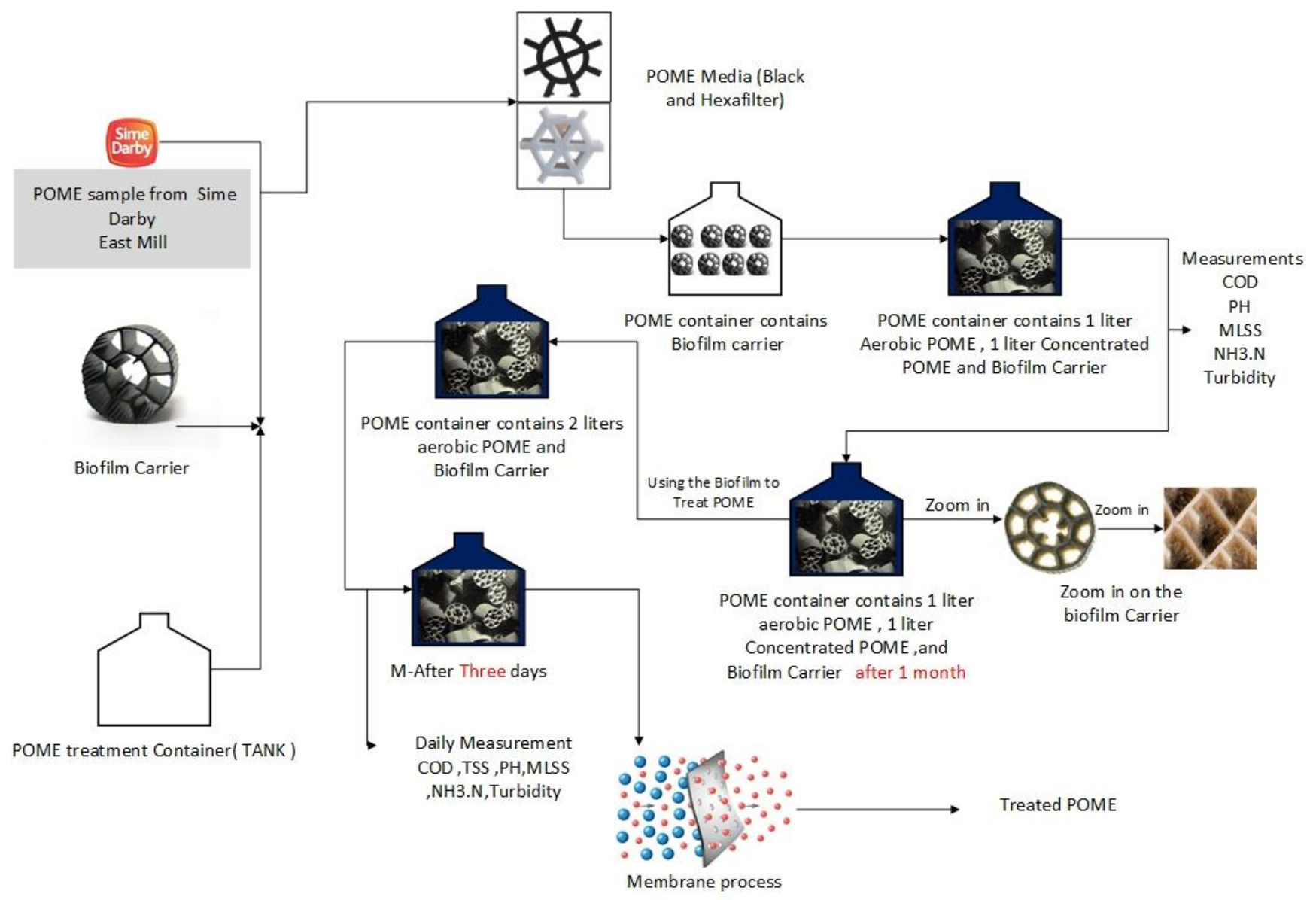

Figure 1 Map of the treatment system

\subsection{Membrane Treatment}

Membrane filtration performed further treatment for the POME after the biofilm treatment. A laboratory bench- scale crossflow test unit was used to study the performance of NF270 membrane in treating the effluent after the biofilm treatment. NF270 membrane was cut into a rectangular shape with a practical membrane filtration area $120 \mathrm{~cm}^{2}$. The membrane filtration processed POME at the transmembrane pressure (TMP) of 3 bar. Water permeates after the membrane filtration process was collected and analysed by finding TSS, Dissolved oxygen, NH3-N, MLSS, pH, Turbidity, and COD range.

\subsection{Analysis Methods}

The effluent quality presents the performance of the system based on $\mathrm{pH}$, chemical oxygen demand (COD), mixed liquor suspended solids (MLSS), ammoniacal nitrogen (NH3-N), dissolved oxygen (DO), turbidity, and total suspended solids (TSS) concentration. The $\mathrm{pH}$ of the sample was measured using $\mathrm{pH}$ meter, 827 Metrohm (Metrohm, Malaysia).

DO of the sample was measured using portable YSI 550A DO meter (YSI, USA). The turbidity of the sample was measured using $\mathrm{HACH} 2100 \mathrm{~N}$ laboratory
Turbidimeter ( $\mathrm{HACH}$, Malaysia). Whereas, the measurement of TSS was done using HACH DR 3900 equipment ( $\mathrm{HACH}$, Malaysia). The COD analysis was done by preheating the sample at $150^{\circ} \mathrm{C}$ for 2 hours in DRB 200 reactor and analysed using HACH DR 3900 Benchtop Spectrophotometer ( $\mathrm{HACH}$, Malaysia) after cooled to room temperature. Nessler method made by HACH DR 3900 Benchtop Spectrophotometer (HACH, Malaysia) to present NH3-N concentration of the sample.

\subsection{RESULTS AND DISCUSSIONS}

\subsection{Acclimatization of Biofilm}

The objective of this study was to investigate POME treatment by using different growth media (biofilm carriers). This study had aimed to get high-quality pretreatment. First of all, this research started with biofilm development and bacteria growth. The bacteria produce different size of biofilm layers on the media surface. By employing these bacteria to create more biofilm, the treatment delivers sufficient biodegradation process against POME contaminants. It is not easy to occupy these bacteria because it has a challenging mood to be satisfied. 
Biofilm bacteria need several conditions to be suitable for its growth. When the biofilm growth stage started, several measurements were done to check the progress of POME treatment. COD, and DO test presented the progress of the biofilm bacteria through the biodegradation. Biofilm bacteria are not giving free treatment for POME; it needs food to work entirely by doing remarkable pre-treatment. POME bacteria need many kinds of food like oxygen and nutrients.

The biological growth results showed the process path with the best duration. COD reduction by both carriers is close which is $67 \%$ removal by the hexafilter carrier, and $58 \%$ by the black media with respect to MLSS, turbidity, and ammoniacal nitrogen removal ranges at 15 days duration, but the action is different due using different designed media. The glass reactor showed the attached biofilm on the growth media. The black media had more biofilm layers than the hexafilter (see Figure 3 and 4).

The media design effects the biofilm attachment process. Since the black media growth is smaller and has more tight corners than the hexafilter media, so the performance to create biofilm was higher efficiency. The biofilm growth at the 15th day is very close to the 27th day of the acclimatisation process by observing COD reduction range. Briefly, 15 days of biofilm growth process showed being a sufficient duration. A study agreed with going for 15 days; it had mentioned that 15 days are sufficient for getting highest removal amount of COD, TSS, and turbidity [15]. Figure 2 presents COD, MLSS, Turbidity, and Ammoniacal nitrogen results at the acclimatisation stage.

In the acclimatisation process, COD level stopped from decreasing at range 2201, and $2450 \mathrm{mg} / \mathrm{l}$ for Hexafilter and black media respectively. COD reduction is linked with biofilm bacteria activity by referring to the required range of oxygen to remediate or eliminate POME pollutants. Bacteria activity was less after few days of acclimatisation process so that COD removal range was less than usual. A researcher employed microalgae to treat POME for 27 days of retention time [15], and the lowest COD range obtained during the 15 th day. It is evident that turbidity range had continued decreasing without stopping for 27 days. For that, turbidity range does not affect biofilm growth or death.

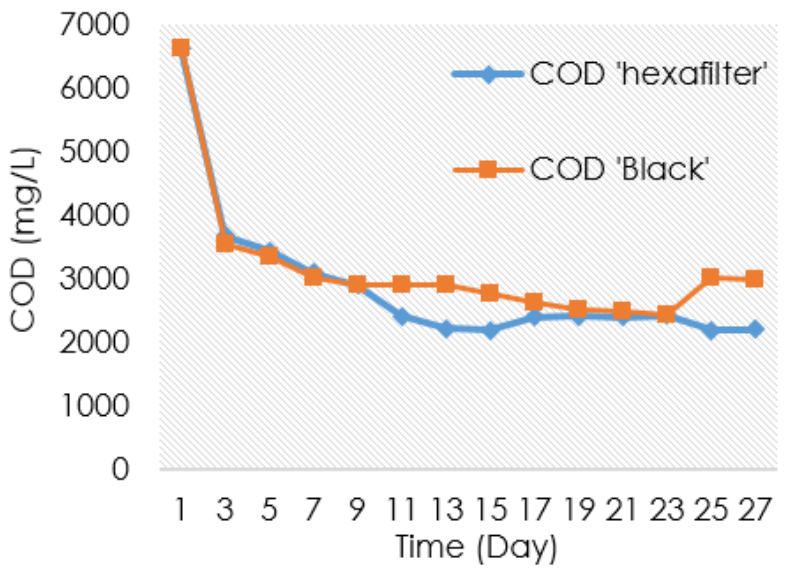

(a) COD vs Time (Day)

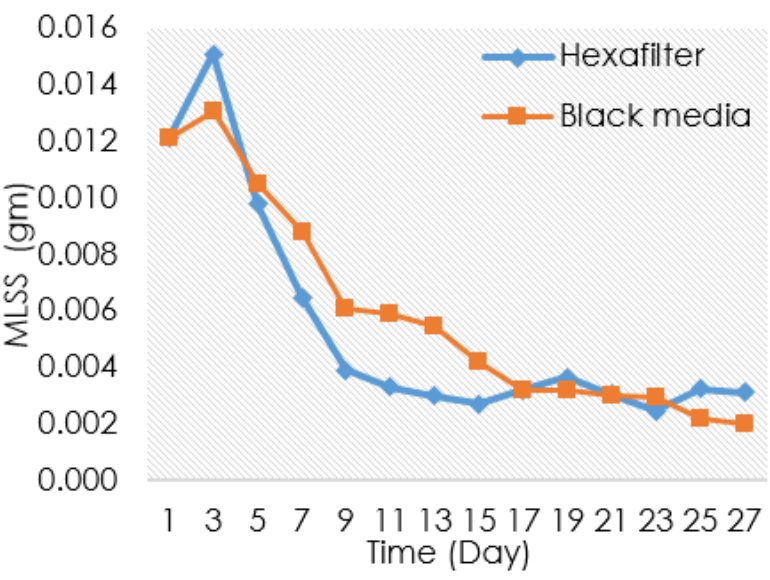

(b) MLSS vs Time (Day)

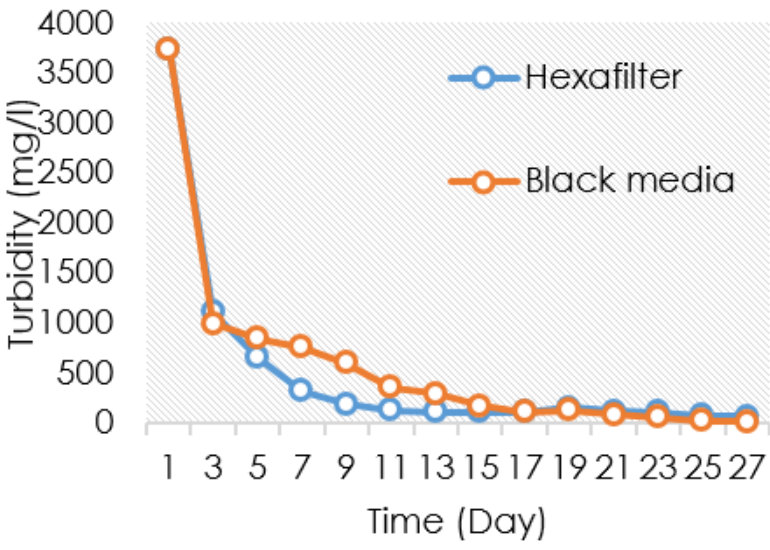

(c) Turbidity vs Time (Day) 


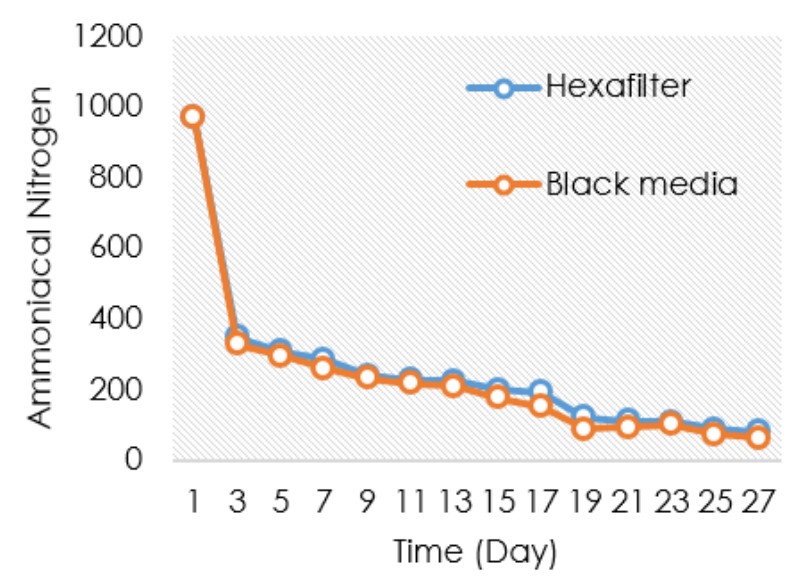

(d) Ammoniacal Nitrogen vs Time (Day)

Figure 2 (a) COD vs Time (Day); (b) MLSS vs Time (Day); (c) Turbidity vs Time (Day); (d) Ammoniacal Nitrogen vs Time (Day)

There is a study confirming 15 days are efficient to get maximum turbidity removal, and that is contrast [16]. The study used microalgae as dominant microorganisms for POME treatment which had 7.48,
$4045 \mathrm{mg} / \mathrm{l}, 334 \mathrm{mg} / \mathrm{l}, 607 \mathrm{mg} / \mathrm{l}$, and $395.5 \mathrm{NTU}$ of $\mathrm{pH}$, COD, NH3-, TSS, and turbidity.

Ammoniacal nitrogen test was taken for 27 days of biofilm evolution. Ammoniacal nitrogen range had reduced gradually within all biofilm growth duration.

Both biofilm media achieved close ranges of ammoniacal nitrogen removal which are $107 \mathrm{mg} / \mathrm{l}$ for hexafilter, and $91 \mathrm{mg} / \mathrm{l}$ for black media after 48 hours of POME biotreatment. Environmental conditions like temperature and light intensity were not maintained. Fifteen days are not enough to gain the best removal amount of ammoniacal nitrogen. Also, the difference between 27th and 15th day of ammoniacal nitrogen removal amount is nearly $15 \%$ for both sorts of media.

The duration of optimal biofilm growth was unknown, so this research sought the perfect duration to get the highest size of biofilm growth. In this study, within 15 days, the biofilm growth reached its maximum. COD test could show when the bacteria stop from developing the biofilm. COD test results were the key to inspect biofilm bacteria activity. Within time, the biological film developed on the growth media surface by numerous microorganisms (see Figure 3, and Figure 4).

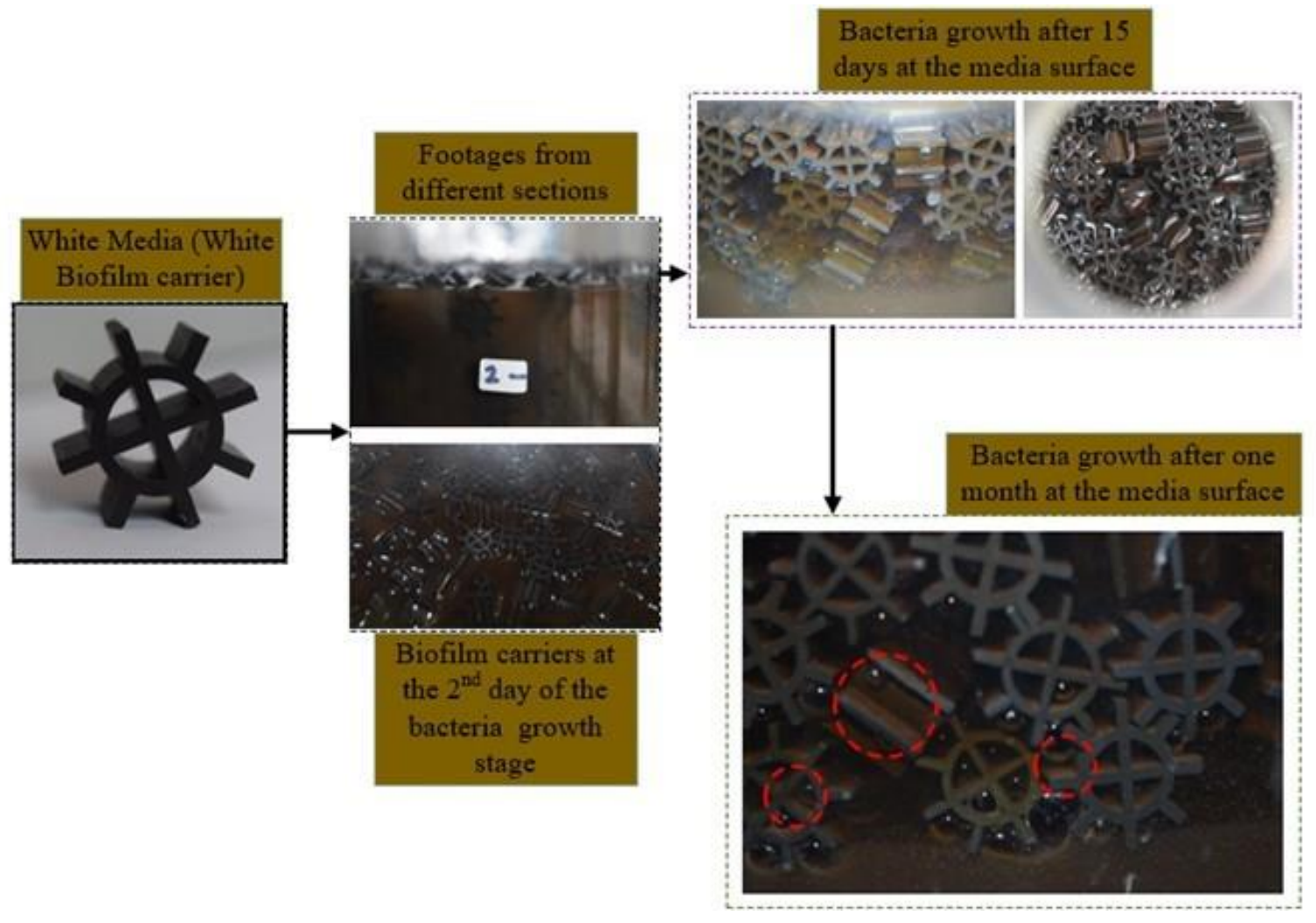

Figure 3 Footages of biofilm evolution during time (Black Media) 


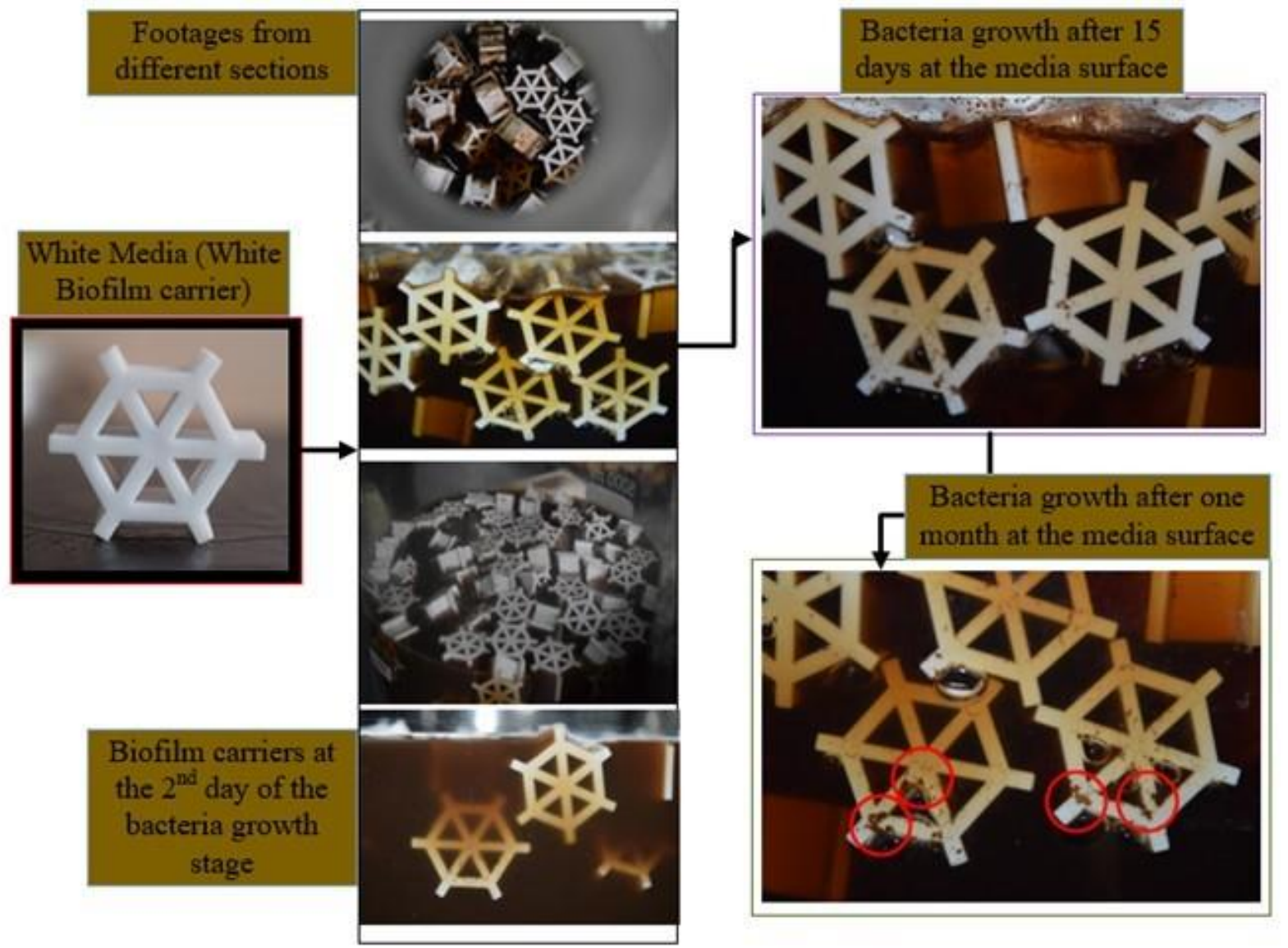

Figure 4 Footages of Biofilm development with time (Hexafilter media)

\subsection{Biofilm Treatment}

This biofilm growth made by the occupied bacteria in the POME medium. POME treatment had started after reaching maximum growth, as shown in Table 3. POME treatment with high availability of biofilm should give a high efficiency to pretreat the wastewater.

It seems the black media consumed more time than the hexafilter media to reach what hexafilter media reached in treating POME. The treatment achieved the highest percent of reduction after 24 hours of the treatment age. In addition, the treatment lost its efficiency after 24 hours of the treatment age, because every single bacterium had achieved its maximum utilisation and can't go further. Thus, this biological treatment can give a specific removal amount of COD. Another study used HRT for 12 days and had reached $92.7 \%$ reduction of COD, with using aerobic conditions, similar to the occurred study [17]. A researcher had used polymeric media for treating POME with anaerobic conditions, COD reduction range was $60 \%$, and the used raw POME had COD range around $2100 \mathrm{mg} / \mathrm{l}$ [18]. Biofilm treatment had achieved good performance by comparing with other researches.

Table 3 Properties of aerobic digested POME and the biological biofilm treatment results

\begin{tabular}{|c|c|c|c|c|c|c|c|c|}
\hline & & & & Hexafilter & & Black media & & \\
\hline Parameters & $\begin{array}{c}\text { Aerobic } \\
\text { POME }\end{array}$ & $24 \mathrm{hr}$. & $48 \mathrm{hr}$. & $72 \mathrm{hr}$. & $24 \mathrm{hr}$. & $48 \mathrm{hr}$. & $72 \mathrm{hr}$. & Unit \\
\hline COD & 1450 & 760 & 1130 & 850 & 690 & 910 & 1040 & $m g \backslash I$ \\
\hline Turbidity & 87.9 & 140 & 122 & 93 & 130 & 111 & 76 & NTU \\
\hline $\mathrm{pH}$ & 8.021 & 7.258 & 7.422 & 7.651 & 7.654 & 7.973 & 7.855 & $m g \backslash I$ \\
\hline MLSS & 0.006 & 0.0031 & 0.0025 & 0.0025 & 0.0035 & 0.0026 & 0.0032 & $m g \backslash I$ \\
\hline $\mathrm{NH} 3-\mathrm{N}$ & 101 & 93 & 100 & 107 & 102 & 86 & 93 & $m g \backslash I$ \\
\hline Temperature & 25.7 & - & - & - & - & - & - & ${ }^{\circ} \mathrm{C}$ \\
\hline $\begin{array}{l}\text { Dissolved } \\
\text { oxygen }\end{array}$ & 2.03 & 1.88 & 2.49 & 2.71 & 2.38 & 1.79 & 2.57 & $m g \backslash I$ \\
\hline TSS & 290 & 140 & 420 & 405 & 340 & 470 & 410 & $m g \backslash I$ \\
\hline
\end{tabular}




\subsection{Membrane Treatment}

The treatment of POME by NANO membrane is super- efficient by noticing the removal amount (see Table 4). In this case, NANO membrane is very efficient to use, and no need to go for extreme treatment like RO. As known, the membrane has a common problem known as fouling. There is a study had occurred on treating POME by using Ultrafilter (UF) membrane [19]. The used POME had COD range $12040 \mathrm{mg} / \mathrm{l}$, after using UF treatment, POME COD range decreased within $94.8 \%$ from the used $\mathrm{POME}$, but NF removed $97.94 \%$ of COD in this research. Also, Said and Mohammad (2015) used UF and NF together to treat POME; the achieved reduction percent of COD was around 97.29\% [19]. Another researcher integrated microalgae with UF membrane, and COD reduction was around $90.3 \%$ [16].

After reviewing these researches, it is evident that integrating biofilm treatment with NF membrane produced well-treated POME with around 98.6, 99.98, 97.5, 99.87\% reduction of COD, turbidity, MLSS, and Ammoniacal nitrogen, respectively. Table 4 shows the properties of POME feed and membrane discharge. Additionally, the discharged water is complying with the III, and the IV class of the National Water Quality standards of Malaysia for water supply (Extensive treatment is required), and fishery (livestock drinking) purpose [20].

Table 4 POME properties at the feed and outlet stage

\begin{tabular}{llll}
\hline & Feed & Treated POME & \\
\hline Properties & Value & Value & Units \\
\hline COD & 923 & 19 & $\mathrm{mg} / \mathrm{l}$ \\
TSS & 409.5 & 0 & $\mathrm{mg} / \mathrm{l}$ \\
MLSS & 0.003 & 0.0003 & $\mathrm{mg} / \mathrm{l}$ \\
$\mathrm{DO}$ & 2.6 & 4.44 & $\mathrm{mg} / \mathrm{l}$ \\
NH3-N & 98 & 1.19 & $\mathrm{mg} / \mathrm{l}$ \\
Turbidity & 80 & 0.381 & $\mathrm{NTU}$ \\
$\mathrm{pH}$ & 7.81 & 6.473 & - \\
\hline
\end{tabular}

\subsection{CONCLUSION}

Many factors affected the whole process efficiency. The surface area for biofilm media should be large enough to provide an attractive surface to get a large and useful attachment. The growth media surface should be crimped to stop the eruption. The liquid movement develops a severe eruption of the microscopic colonies. The water movement causes a break to the attached biofilm; then the pre-treatment performance goes down. Biofilm media should involve small corners. These small corners are helpful to save biofilm bacteria from the removal and the disruption. Lastly, NF results showed an excellent treatment for POME. Thus, using NF is very compatible with biofilm treatment.

\section{Acknowledgement}

The authors declare no competing financial interests.

\section{References}

[1] Loan, W. Azraai, M. Kheang, S. Chioma. 2015 Conventional Methods and Emerging Wastewater Polishing Technologies for Palm Oil Mill Effluent Treatment: A Review. Journal of Environmental Management.

[2] Mohammadi. Ibrahim, P. Annuar, S. Khashij, M. Mousavi, M. Zinatizadeh, S. Aliakbar. 2016. Optimization of Fermentative Hydrogen Production from Palm Oil Mill Effluent in an Up-flow Anaerobic Sludge Blanket Fixed Film Bioreactor. Sustainable Environment Research.

[3] Ng, Y. Lim, S. Chan, R. Chieh, D. 2016. Development of Treated Palm Oil Mill Effluent (POME) Culture Medium for Plant Tissue Culture of Hemianthus Callitrichoides. Journal of Environmental Chemical Engineering.

[4] Lamizana, Birguy D. ais.unwater. [Online]. Available: www.ais.unwater.org/ais/pluginfile.php/501/mod_page/c ontent/87/SUWA GPA presentation - Bali 040313.pdf.

[5] F, Chow. Mei, F. Yi, J. 2015. A New Energy Source from the Anaerobic Co-digestion (Acd) Treatment of Oleo Chemical Effluent with Glycerin Pitch. Asia-Pacific Journal of Chemical Engineering.

[6] Najib, M. Ibrahim, Z. Salim, M. Ujang, Z. 2017. Developed Microbial Granules Containing Photosynthetic Pigments for Carbon Dioxide Reduction in Palm Oil Mill Effluent. International Biodeterioration \& Biodegradation.

[7] Rupani, P. Singh, F. Ibrahim, R. Esa, M. 2010. Review of Current Palm Oil Mill Effluent (POME) Treatment Methods: Vermicomposting as a Sustainable Practice. World Applied Sciences Journal.

[8] Ma, Ngan A. 2000. Environmental Management for the Palm Oil Industry.

[9] Veolia, W. Access Date [22 November 2016]. ANOXKALDNESTM MBBR. [Online]. Available: http://technomaps.veoliawatertechnologies.com/proces ses/lib/pdfs/productbrochures/anox/DE96X46q57VLAFRUI CYUamGQ.pdf.

[10] Lazarova, V. Manem. Jacques. 2000. Innovative Biofilm Treatment Technologies for Water and Wastewater Treatment. Chemlnform.

[11] Broens, H. Knops, F. Hoof, V. 2007. Economic Evaluation of a New Ultrafiltration Membrane for Pretreatment of Seawater Reverse Osmosis. Desalination. 203: 300-306.

[12] Wu, T. Mohammad, A. Jahim, W. Anuar, J. Nurina. 2007. Palm Oil Mill Effluent (POME) Treatment and Bioresources Recovery Using Ultrafiltration Membrane: Effect of Pressure on Membrane Fouling. Biochemical Engineering Journal.

[13] Bagheripour, E. Moghadassi, A. Hosseini, S. 2015. Fabrication of Polyvinyl Chloride based Nanocomposite Nanofiltration Membrane: Investigation of SDS/Al2O3 Nanoparticle Concentration and Solvent Ratio Effects. Asia-Pacific Journal of Chemical Engineering.

[14] Igwe. Onyegbado, J. CC. 2007. A Review of Palm Oil Mill Effluent (POME) Water Treatment. Global Journal of Environmental Research.

[15] Ibrahim, R. Mohammad, A. Wong, Z. 2015. Optimization of POME Treatment Process Using Microalgae and Ultrafiltration. Membrane Water Treatment.

[16] Ibrahim, R. Wong, Z. Mohammad, A. 2015. Optimization and Performance Evaluation for Nutrient Removal from Palm Oil Mill Effluent Wastewater Using Microalgae. IOP Conference Series: Materials Science and Engineering.

[17] Chou, K. Tan, S. Morad, W. Tow, N. Kadir, A. Ismail, A. Norli. 2016. Aerobic Post-treatment of Different Anaerobically Digested Palm Oil Mill Effluent (POME). International Journal of Environmental Science and Development. 
172 Al-Amshawee Sajjad, Yeit Haan Teow \& Abdul Wahab / Jurnal Teknologi (Sciences \& Engineering) 80:4 (2018) 165-172

[18] Malakahmad, A. Yee, A. Witton. 2014. Production of Energy from Palm Oil Mill Effluent During Start-up of Carrier Anaerobic Baffled Reactor (CABR) Equipped with Polymeric Media. Journal of the Japan Institute of Energy.

[19] Said, M. Mohammad, A. Nor, A. Abdullah, S. Sheikh, R. Hasan, Abu H. 2015. Investigation of Three Pre-treatment
Methods Prior to Nanofiltration Membrane for Palm Oil Mill Effluent Treatment. Sains Malaysiana.

[20] Anonynoums. 2010. Wepa. Water Environment Partnership in Asia. [Online]. Available: http://www.wepadb.net/policies/law/malaysia/eq_surface.htm. 